\title{
Synthesis of trialkyl 2-halogeno-1,1,1-ethanetricarboxylates
}

\author{
Juan Zinczuk* and Gustavo A. Carnavale \\ Instituto de Química Rosario (CONICET-UNR . Facultad de Ciencias \\ Bioquímicas y Farmacéuticas Universidad Nacional de Rosario. Suipacha 531- 2000 Rosario - \\ Argentina \\ E-mail:jzinczuk@fbioyf.unr.edu.ar
}

\section{DOI: $\underline{\text { http://dx.doi.org/10.3998/ark.5550190.p009.567 }}$}

\begin{abstract}
A series of trialkyl 2-halogeno-1,1,1-ethanetricarboxylates $(\mathrm{Hal}=\mathrm{Cl}, \mathrm{Br}, \mathrm{I})$ was obtained in high yields by halomethylenation of trialkyl methanetricarboxylates that in turn were derived from dialkyl malonates. The variables that control the reaction (solvent, temperature, time of reaction, base, and alkylating agent) were adjusted to optimize the yield. This new family of compounds may be considered as synthetic equivalents of the unstable dialkyl (halomethyl)malonates.
\end{abstract}

Keywords: Halomethylenation, dialkyl (halomethyl)malonates, trialkyl 2-halogeno-1,1,1ethanetricarboxylates, optimized synthesis.

\section{Introduction}

We are interested in the reactivity of metallic homoenolates, formally derived from dialky methylmalonates, and proposed the metallation of the appropriate dialkyl (halomethyl)malonates as a method of preparation. Dialkyl (halomethyl)malonates are scarcely referenced in the literature. The only reported example corresponds to diethyl (bromomethyl)malonate, obtained in impure form by Simonsen by reaction of diethyl (2-methoxymethyl)malonate and hydrobromic acid. ${ }^{1}$ More recently Dowd and Shapiro improved the compound purity but recognized the sensible nature of the bromo compound. ${ }^{2}$

The study of the halomethylenation of dialkylmalonates began more than a century. The reaction of diethyl malonate (1) and diiodomethane in the presence of sodium ethoxide was first reported by Guthzeit and Dressel in 1888. 3,4 They used a half equivalent of diiodomethane and obtained $84 \%$ of tetraethyl 1,1,3,3-propanetetracarboxylate (2).

Perkin and Prentice obtained the same compound in 60\% yield replacing diiodomethane by dichloromethane and conducted the reaction in a closed vessel. ${ }^{5}$ In turn, F. Tutin carried out the reaction under identical conditions but obtained only $20 \%$ of product. ${ }^{6}$ Using diiodomethane in 
place of dichloromethane he obtained a mixture of unreacted $\mathbf{1}$ and diethy methylenemalonate (3). The expected 2 was not detected. N. Zielinsky also investigated the reaction using a 1:1:1 molar ratio of $\mathbf{1}$, diiodomethane and sodium ethoxide and postulated the intermediate formation of diethyl (iodomethyl)malonate (4), which under the reaction conditions eliminates $\mathrm{HI}$ to give $\mathbf{3}$ that, in turn, suffers Michael addition by the anion of 1 to yield $\mathbf{2}$ (Scheme 1). ${ }^{7}$

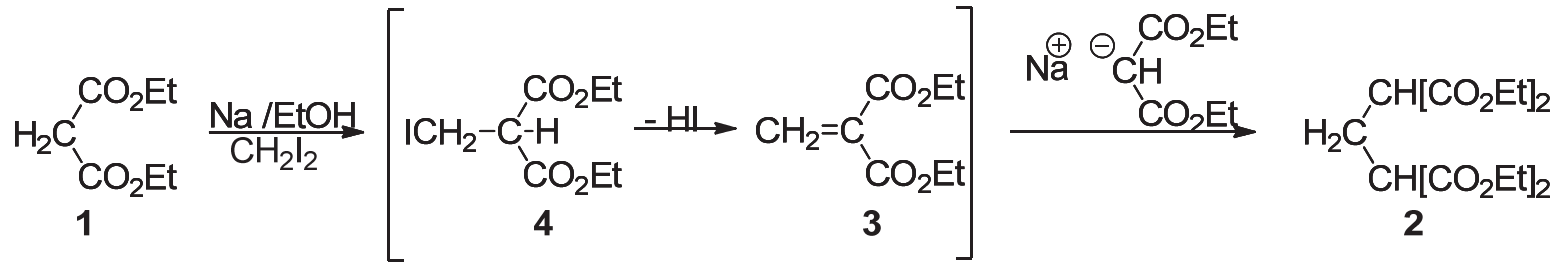

Scheme 1. Reaction of diethyl malonate with diiodomethane.

We have carried out the reaction using similar conditions and analyze the products by gas chromatography-mass spectrometry. Only three peaks are observed that correspond to diodomethane $(13 \%), 2(84 \%)$ and a product of condensation of diiodomethane and three molecules of $1(3 \%)$.

As a conclusion, the compounds obtained by the condensation of dihalomethanes and the sodium enolate of $\mathbf{1}$ vary according to the conditions under which the reaction takes place, but in no case, the diethyl (halomethyl)malonate could be detected because, under the basic conditions of the reaction, the methinic hydrogen atom is removed together with the halogen atom and the generated $\mathbf{3}$ is attacked by the anion of $\mathbf{1}$. For this reason, it is necessary to replace an acidic methylenic hydrogen atom of the dialkyl malonate by an effective protecting group previous to halomethylenation. As a model we analyzed the reactions of dialkyl alkylmalonates with diiodomethane.

The products of the reaction depend on the reaction conditions and the proportions of reagents. Thus, Auwers and Thorpe reported the reaction of diiodomethane, diethyl methylmalonate (5) and sodium ethoxide in ethanol using a 1:2:2 ratio to give tetraethyl 1,3dimethyl 1,1,3,3-propanetetracarboxylate (6). ${ }^{8}$ In turn, Kötz and Zörnig reacted diethyl ethylmalonate (7) and sodium in ether and then with an excess of diiodomethane to obtain diethyl (2-iodomethyl)ethylmalonate (8) (Scheme 2). ${ }^{9}$

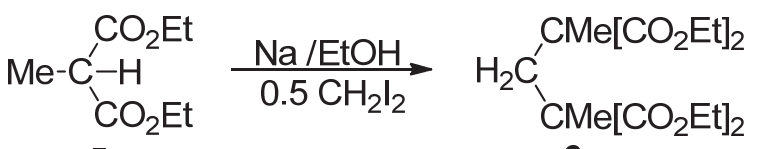

5
6

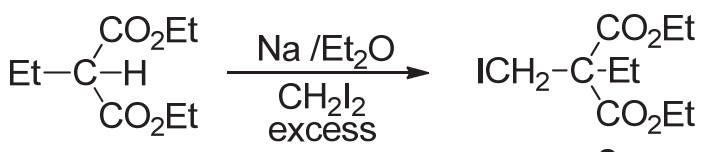

7

Scheme 2. Reaction of diethyl alkylmalonates with diiodomethane. 
In view of these results, we decided to substitute one methylenic hydrogen atom of the dialkyl malonate by an effective protecting group that could be easily deblocked at the final stage of the reaction. Following the strategy developed by Rapoport et al. ${ }^{10}$ we choose an alkoxycarbonyl group as the protecting group (Scheme 3).

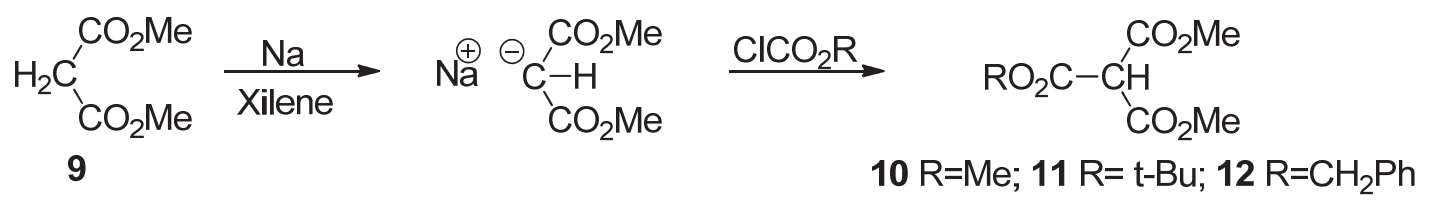

Scheme 3. Preparation of trialkyl methanetricarboxylates.

The resulting trialkyl methanetricarboxylates obtained in high yield from dialkyl malonate and the appropriate alkyl chloroformate ${ }^{11}$ may be viewed as a synthetic equivalent of the original dialkyl malonate, with the advantage that there is only one acidic hydrogen atom to be eliminated under basic conditions to form the corresponding enolate which is an appropriate substrate for the halomethylenation reaction.

For practical reasons, starting with dimethyl malonate (9), we use three different protecting group alternatives: 1) methoxicarbonyl group to generate the high symmetric trimethyl methanetricarboxylate (10). This group can be deprotected by different reagents, ${ }^{10}$ for example with boron trichloride in dichloromethane at $5{ }^{\circ} \mathrm{C}, 2$ ) tert-butoxycarbonyl (BOC) group to give tert-butyl dimethyl methanetricarboxylate (11) that can be deprotected selectively by acidic workup, and 3) benzyloxycarbonyl (CBZ) group to give benzyl dimethyl methanetricarboxylate (12) that allow their selective cleavage by hydrogenolysis.

The trialkyl methanetricarboxylates are easily converted into the sodium or potassium salt by the reaction with the respective metal alkoxides. The resulting enolates are readily alkylated in high yield with alkyl halides or sulfates in different solvents such as acetone, dioxane and a 1:1 mixture of benzene and dimethylformamide (DMF). ${ }^{10-15}$ Thus, for example, trimethyl sodiomethanetricarboxylate (10a) or trimethyl potassiomethanetricarboxylate $(\mathbf{1 0 b})$ reacts with iodomethane in dioxane at reflux to give $90 \%$ of trimethyl $1,1,1$-ethanetricarboxylate (13) ${ }^{14}$ and 10a reacts with 1,4-dibromobutane in a $1: 1$ mixture of benzene and DMF at $80{ }^{\circ} \mathrm{C}$ for $20 \mathrm{~h}$ to give trimethyl 5-bromopentane 1,1,1-tricarboxylate (14) in 70\% yield. ${ }^{10}$ (Scheme 4).

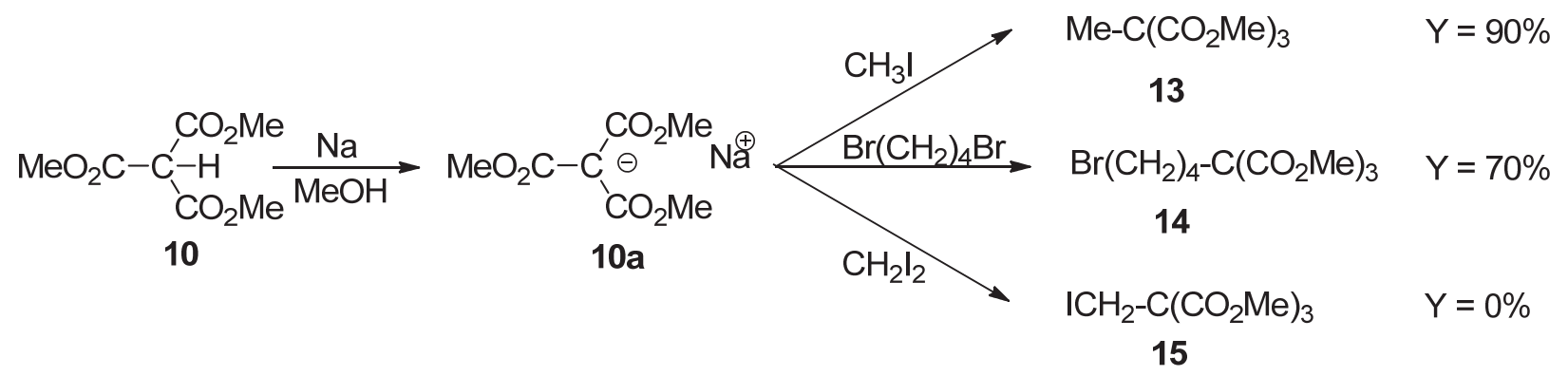

Scheme 4. Reaction of trialkyl methanetricarboxylates with haloalkanes. 


\section{Results and Discussion}

\section{Halomethylenation of trialkyl methanetricarboxylates.}

Applying the conditions mentioned above to methylating (10a) but using diiodomethane as alkylating agent, we observed that no trimethyl 2-iodo-1,1,1-ethanetricarboxylate (15) was formed (Scheme 4).

This striking reactivity difference could be mainly attributed to the heterogeneous character of the reaction and the great size and different reactivity of the diiodomethane as alkylating agent. To improve the halomethylenation we analyzed the main factors that could affect the reaction including the solvent, temperature, time of reaction, and the base used.

(i) Solvent. 10a is sparingly soluble in dioxane, ether, benzene and other solvents of low polarity and no reaction with diiodomethane in these solvents was observed. Otherwise, polar solvents are expected to solubilize the salt and facilitate the reaction. Polar protic solvents like methanol, though they solubilize the salt, are inappropriate because they protonate or solvate the anion through hydrogen bonds and reduce their basic and nucleophilic character. On the other hand, aprotic polar solvents like DMF and dimethylsulfoxide (DMSO) easily solubilize the salt but solvate poorly the anion that enhances its nucleophilic character. ${ }^{16}$

The effects of solvent on the yield of $\mathbf{1 5}$ are given in Table 1.

Table 1. Reaction of 10a and $10 \mathrm{~b}$ with diiodomethane

\begin{tabular}{ccccc}
\hline Solvent & Substrate & Time $[\mathrm{h}]$ & Temp. $\left[{ }^{\circ} \mathrm{C}\right]$ & $\mathbf{1 5}$ \%Yield \\
\hline Dioxane & $\mathbf{1 0 a}$ & 12 & 100 & 0 \\
Methanol & $\mathbf{1 0 a}$ & 12 & 60 & 0 \\
THF & $\mathbf{1 0 a}$ & 12 & 66 & 0.3 \\
Benzene-DMF 1:1 & $\mathbf{1 0 a}$ & 12 & 70 & 27 \\
DMF & $\mathbf{1 0 a}$ & 12 & 60 & 39 \\
DMSO & $\mathbf{1 0 a}$ & 12 & 70 & 61 \\
DMSO & $\mathbf{1 0 b}$ & 12 & 70 & 71 \\
\hline
\end{tabular}

The homogeneous reaction carried out in DMF yields $39 \%$ of $\mathbf{1 5}$, whereas in DMSO the yields are $61 \%$ for $\mathbf{1 0 a}$ and $71 \%$ for $\mathbf{1 0 b}$. This difference may be attributed to the more nucleophilic enolate anion of $\mathbf{1 0}$ when potassium is the counter metal cation. 
(ii) Temperature and time. The range of temperature was varied between 20 and $100{ }^{\circ} \mathrm{C}$ and the reaction time between 3 and $30 \mathrm{~h}$. Based on the experimental results, we fixed the optimal values at $70{ }^{\circ} \mathrm{C}$ and $12 \mathrm{~h}$ respectively.

(iii) Salt preformation versus in situ formation. A new alternative procedure to the use of 10a or $\mathbf{1 0 b}$ in the halomethylenation reaction, starts from $\mathbf{1 0}$ and an appropriate base to generate the corresponding anion. The in situ formed enolate, depending on the base used, would be associated with different counter metal cations as ion pairs. The rate of halomethylation would depend on the extension of this association which is a function of the particular cation employed.

Compound $\mathbf{1 0}$ is a relative acidic compound with a $\mathrm{pKa}=7.8$ and a moderate strong base is enough to deprotonate and form its enolate, previous to reaction with dihalomethanes. (Scheme $5)$.

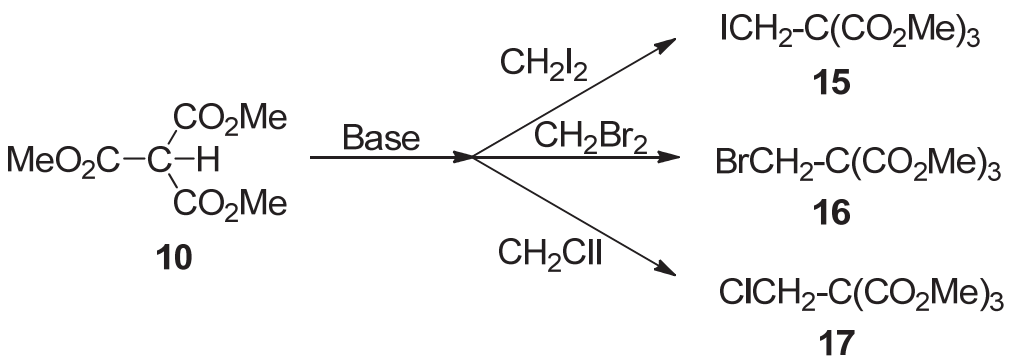

Scheme 5. Improved synthesis of trimethyl 2-halogeno-1,1,1-ethanetricarboxylates.

Several bases were compared for the reaction of $\mathbf{1 0}$ and dibromomethane in DMSO. The results are listed in Table 2.

Table 2. Base effects on the yield of $\mathbf{1 6}$ by reaction of $\mathbf{1 0}$ and $\mathrm{CH}_{2} \mathrm{Br}_{2}$ in DMSO at $70{ }^{\circ} \mathrm{C}$ for $12 \mathrm{~h}$

\begin{tabular}{ccc}
\hline Base & pKa & $\mathbf{1 6} \%$ Yield $(*)$ \\
\hline $\mathrm{DBN}$ & 12.7 & 36 \\
$\mathrm{MeONa}$ & 15.5 & 34 \\
$\mathrm{Li}_{2} \mathrm{CO}_{3}$ & 10.3 & 21 \\
$\mathrm{Na}_{2} \mathrm{CO}_{3}$ & 10.3 & 69 \\
$\mathrm{~K}_{2} \mathrm{CO}_{3}$ & 10.3 & 94 \\
$\mathrm{Cs}_{2} \mathrm{CO}_{3}$ & 10.3 & 96 \\
\hline
\end{tabular}

(*) analyzed by GC-Mass spectrometry.

The reaction of 10 and $\mathrm{CH}_{2} \mathrm{Br}_{2}$ using 1,5-diazabicyclo[4.3.0]non-5-ene (DBN) gives a mixture of $36 \%$ of the desired 16, 12\% of the starting 10 and several other condensation products between 10 and 16. With sodium methoxide the yield of the product also is low (34\%). The main 
coproduct corresponds to $13(49 \%)$, the reduction product of 16 . The use of alkaline carbonates gives yields between 21 and 96\%. The higher yields correspond to potassium and cesium carbonate.

(iv) Effect of counterion. A comparison of the product yields using as base alkaline carbonates, shows that the reactivity of the enolate ion is influenced by the nature of the counter metal cation.

Lithium cation forms the more tightly associated enolate-cation ion pair that reduces its nucleophilicity. The more reactive free enolate anions are likely to predominate in dipolar aprotic solvents that solvate the cation but leave free the enolate anion. In this way, the less associated potassium or cesium enolates are the more reactive and give $\mathbf{1 6}$ in excellent yield. As expected, sodium carbonate as a base gives an intermediate yield.

(v) Effect of the halogen. The reactivity of various dihalomethanes as alkylating agent for $\mathbf{1 0}$ correlates with the order observed for other bimolecular nucleophilic displacement reactions. The iodide is slightly more reactive than the bromide which is much more reactive than the chloride. Applying the optimal conditions previously established for the reaction of $\mathbf{1 0}$ and dibromomethane, several trialkyl 2-halogeno-1,1,1-ethanetricarboxylates were obtained. The results are summarized in Table 3.

Table 3. Yields of trialkyl 2-halogeno-1,1,1-ethanetricarboxylates

\begin{tabular}{ccccc}
\hline Substrate & Base & Dihalomethane & Product & \%Yield \\
\hline $\mathbf{1 0}$ & $\mathrm{K}_{2} \mathrm{CO}_{3}$ & $\mathrm{CH}_{2} \mathrm{I}_{2}$ & $\mathbf{1 5}$ & 95 \\
$\mathbf{1 0}$ & $\mathrm{Cs}_{2} \mathrm{CO}_{3}$ & $\mathrm{CH}_{2} \mathrm{I}_{2}$ & $\mathbf{1 5}$ & 97 \\
$\mathbf{1 0}$ & $\mathrm{Cs}_{2} \mathrm{CO}_{3}$ & $\mathrm{CH}_{2} \mathrm{Cl}_{2}$ & $\mathbf{1 7}$ & 1.3 \\
$\mathbf{1 0}$ & $\mathrm{K}_{2} \mathrm{CO}_{3}$ & $\mathrm{CH}_{2} \mathrm{ClI}$ & $\mathbf{1 7}$ & 89 \\
$\mathbf{1 0}$ & $\mathrm{Cs}_{2} \mathrm{CO}_{3}$ & $\mathrm{CH}_{2} \mathrm{ClI}$ & $\mathbf{1 7}$ & 84 \\
$\mathbf{1 0}$ & $\mathrm{Cs}_{2} \mathrm{CO}_{3}$ & $\mathrm{CH}_{2} \mathrm{Br}_{2}$ & $\mathbf{1 6}$ & 96 \\
$\mathbf{1 0}$ & $\mathrm{Cs}_{2} \mathrm{CO}_{3}$ & $\mathrm{CH}_{2} \mathrm{BrI}$ & $\mathbf{1 5}$ & 54 \\
$\mathbf{1 1}$ & $\mathrm{Cs}_{2} \mathrm{CO}_{3}$ & & $\mathbf{1 6}$ & 40 \\
$\mathbf{1 2}$ & $\mathrm{Cs}_{2} \mathrm{CO}_{3}$ & $\mathrm{CH}_{2} \mathrm{I}_{2}$ & $\mathbf{1 8}$ & 92 \\
\hline
\end{tabular}

Diiodomethane reacts with $\mathbf{1 0}$ and the potassium or cesium carbonate in DMSO with yields comparable to dibromomethane, whereas dichloromethane, even in a closed vessel, only yields $1.3 \%$ of 17 . The replacement of dichloromethane by chloroiodomethane that implies the change of the poor nucleofuge chloride by the effective iodide, ${ }^{17}$ increases the yield of $\mathbf{1 7}$ to $89 \%$. 
The reaction of $\mathbf{1 0}$ and bromoiodomethane shows a competitive displacement between both halogen atoms with a preference for the bromo atom. This preference may be adscribed to the great size of the iodo atom in a reaction with a crowded transition state.

The iodomethylenation reaction was extended to $\mathbf{1 1}$ to give $\mathbf{1 8}$ and $\mathbf{1 2}$ to give $\mathbf{1 9}$ also with high yields. ${ }^{18}$

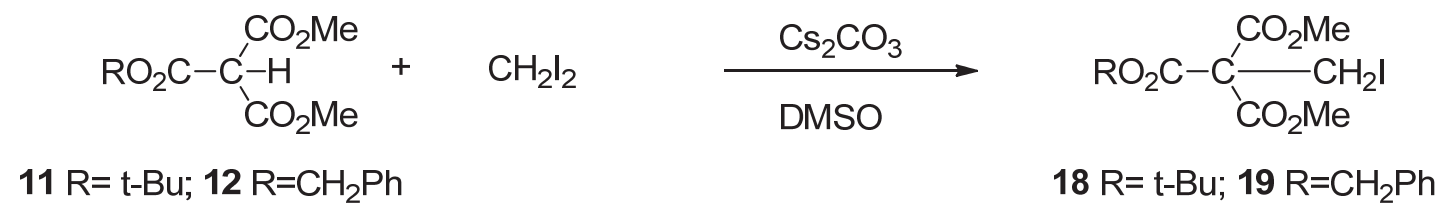

Scheme 6. Synthesis of tert-butyl dimethyl methanetricarboxylate and benzyl dimethyl methanetricarboxylate.

\section{Experimental Section}

General. All reactions were performed under a nitrogen atmosphere in anhydrous solvents and dried glassware. The progress of the reactions was monitored by TLC (Merck silica gel 60F 254 and developed with either a UV lamp $(\lambda=254 \mathrm{~nm})$ or iodine vapor. Flash column chromatography was performed using silica gel 60 (Merck 230-400 Mesh) and hexane- ethyl acetate (90:10) as eluent. Sonications were made in a Testlab cleaning bath, $40 \mathrm{kHz}$. CG-Mass spectra were recorded on a Shimadzu GCMS-QP2010 Plus or Perkin Elmer autosystem XL GC Spectrometer using SE-30, $25 \mathrm{~m}$ x $0.22 \mathrm{~mm}$ column. High resolution mass spectrometry analyses were performed with a Bruker Micro TOF Q-11. ${ }^{1} \mathrm{H}$ and ${ }^{13} \mathrm{C}$ NMR spectra were recorded on a Bruker Avance 300 spectrometer at 300 and $75 \mathrm{MHz}$, respectively. The chemical shifts are given in ppm downfield from TMS. Elemental analyses were performed by Atlantic Microlab, Inc., Norcross, GA (U.S.A.) and Umymform (Argentina). Melting points were measured on an Electrothermal 9100 apparatus and IR spectra were recorded on a FT IR Shimadzu 8101 spectrometer. Anhydrous dioxane was obtained by refluxing and distillation over sodium wire using benzophenone as indicator. DMSO and DMF were dried and distilled from $\mathrm{CaH}_{2}$. Bromoiodomethane and chloroiodomethane were prepared according to literature method. ${ }^{19}$

Trimethyl methanetricarboxylate (10). ${ }^{11}$ According to literature, 9 and sodium in xylene give the enolate that reacts with methyl chloroformate to yield $40 \%$ of $\mathbf{1 0}$. Mp $45-46{ }^{\circ} \mathrm{C}$. (Lit. ${ }^{11} \mathrm{mp}$ $\left.43-45{ }^{\circ} \mathrm{C}\right) .{ }^{1} \mathrm{H}$ NMR $\left(\mathrm{CDCl}_{3}\right) \delta: 3,78\left(\mathrm{~s}, \mathrm{OCH}_{3}, 9 \mathrm{H}\right), 4,43(\mathrm{~s}, \mathrm{CH}, 1 \mathrm{H}) .{ }^{13} \mathrm{C} \mathrm{NMR}\left(\mathrm{CDCl}_{3}\right) \delta$ : $53,29\left(\mathrm{OCH}_{3}\right), 58,36\left(\mathrm{C} 4^{\circ}\right), 164,15(\mathrm{C}=\mathrm{O})$.

Trimethyl sodiomethanetricarboxylate (10a). ${ }^{\mathbf{1 0}}$ An equivalent of sodium methoxide in methanol was added to a solution of $\mathbf{1 0}$ in anhydrous ether, cooled in an ice bath. The insoluble was washed with ether and dried. Yield 95\%. 
Trimethyl potassiomethanetricarboxylate (10b). A solution of $2.55 \mathrm{~g}$. (13 mmol) of 10 in 10 $\mathrm{mL}$ of anhydrous DMSO was added to a solution of $1.50 \mathrm{~g}(13 \mathrm{mmol})$ of potassium tert-butoxide in $50 \mathrm{~mL}$ of anhydrous DMSO at rt. The white suspension was stirred for $1 \mathrm{~h}$, centrifugated, the solid washed with hexane and dried in vacuum at $25^{\circ} \mathrm{C}$. Yield $2.75 \mathrm{~g}(93 \%)$.

Trimethyl 1,1,1-ethanetricarboxylate (13). ${ }^{\mathbf{1 4}}$ To a suspension of $0.212 \mathrm{~g}(1 \mathrm{mmol})$ of the $\mathbf{1 0 a}$ in $5 \mathrm{~mL}$ of anhydrous dioxane were added $0.426 \mathrm{~g}(3 \mathrm{mmol})$ of iodomethane. The reaction tube was sealed with a Teflon stopper and the mixture sonicated at $70{ }^{\circ} \mathrm{C}$ during $12 \mathrm{~h}$. No starting material was detected by TLC. The mixture was cooled to $\mathrm{rt}$ and poured into $10 \mathrm{~mL}$ of water and extracted with ether $(3 \times 10 \mathrm{~mL})$. The combined ether extracts were washed with water $(10 \mathrm{~mL})$ and brine $(10 \mathrm{~mL})$, dried over $\mathrm{Na}_{2} \mathrm{SO}_{4}$ and evaporated. The colorless oil product was pure by GC. Yield $0.184 \mathrm{~g}(90 \%) .{ }^{1} \mathrm{H} \mathrm{NMR}\left(\mathrm{CDCl}_{3}\right) \delta: 1,72\left(\mathrm{~s}, \mathrm{CH}_{3}, 3 \mathrm{H}\right), 3,79\left(\mathrm{~s}, \mathrm{OCH}_{3}, 9 \mathrm{H}\right) .{ }^{13} \mathrm{C} \mathrm{NMR}\left(\mathrm{CDCl}_{3}\right) \delta$ : $18,99\left(\mathrm{CH}_{3}\right), 53,32\left(\mathrm{OCH}_{3}\right), 61,79\left(\mathrm{C}^{\circ}\right), 168,12(\mathrm{C}=\mathrm{O})$.

tert-Butyl dimethyl methanetricarboxylate (11). ${ }^{10}$ To $0.69 \mathrm{~g}(30 \mathrm{mmol})$ of sodium sand in 60 $\mathrm{mL}$ of THF were added $5.22 \mathrm{~g}(30 \mathrm{mmol})$ of tert-butyl methyl malonate. The mixture was stirred and heated at $50{ }^{\circ} \mathrm{C}$ overnight and then cooled in an ice bath. To the cooled and stirred mixture was added dropwise a solution of $4.27 \mathrm{~g}(45 \mathrm{mmol})$ of methyl chloroformate in $10 \mathrm{~mL}$ of THF and then heated at $50{ }^{\circ} \mathrm{C}$ for $1 \mathrm{~h}$, cooled to $\mathrm{rt}$ and poured into a mixture of cold citric acidmonophosphate buffer $(120 \mathrm{ml})$ and ether $(60 \mathrm{~mL})$. The aqueous layer was extracted with ether $(2$ x $40 \mathrm{~mL})$ and the combined ether phase washed with water $(20 \mathrm{~mL})$, brine $(20 \mathrm{~mL})$ and dried over sodium sulfate. The solvent was evaporated and the crude product was purified by distillation as a colorless oil. Bp (0.5 Torr) $100-103{ }^{\circ} \mathrm{C}$. Yield $4.31 \mathrm{~g}(62 \%)$. Anal. Calcd. for $\mathrm{C}_{10} \mathrm{H}_{16} \mathrm{O}_{6}: \mathrm{C}, 51.72 ; \mathrm{H}, 6.94$. Found: $\mathrm{C}, 51.65 ; \mathrm{H}, 7.10 .{ }^{1} \mathrm{H} \mathrm{NMR}\left(\mathrm{CDCl}_{3}\right) \delta: 1.45\left(\mathrm{~s},{ }^{\mathrm{t}}-\mathrm{Bu}\right.$, $9 \mathrm{H}), 3.77\left(\mathrm{~s}, \mathrm{OCH}_{3}, 6 \mathrm{H}\right),\left(4.32(\mathrm{~s}, \mathrm{CH}, 1 \mathrm{H}) .{ }^{13} \mathrm{C} \mathrm{NMR}\left(\mathrm{CDCl}_{3}\right) \delta: 27.71\left(\mathrm{CH}_{3}\right), 53.09\left(\mathrm{O}-\mathbf{C H}_{3}\right)\right.$ : $59.61(\mathrm{C}-\mathrm{H}): 83.63\left(\mathrm{O}-\mathrm{CMe}_{3}\right): 162.73\left(\mathrm{CO}_{2}{ }^{\mathrm{t}}-\mathrm{Bu}\right): 164.60\left(\mathrm{CO}_{2} \mathrm{Me}\right)$.

Benzyl dimethyl methanetricarboxylate (12). Dimethyl sodium malonate was prepared by adding a solution of $1.32 \mathrm{~g}(10 \mathrm{mmol})$ of dimethylmalonate in $5 \mathrm{~mL}$ of toluene to a stirring suspension of $0.23 \mathrm{~g}(10 \mathrm{mmol})$ of sodium sand in $10 \mathrm{ml}$ of toluene at reflux. To the cooled $(-10$ $\left.{ }^{\circ} \mathrm{C}\right)$ and stirred white suspension a solution of $1.88 \mathrm{~g}(11 \mathrm{mmol})$ of benzyl chloroformate in 10 $\mathrm{mL}$ of toluene was added dropwise, the mixture heated $3 \mathrm{~h}$ at $\mathrm{rt}$ and then poured into $10 \mathrm{~mL}$ of aqueous $2 \% \mathrm{HCl}$. The organic layer was washed with water, dried over sodium sulfate and the solvent evaporated to give $2.60 \mathrm{~g}$ of crude product as an oil which was purified by column

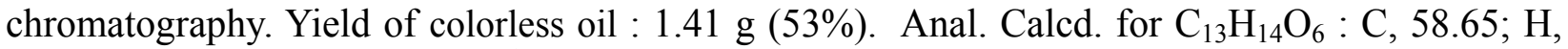
5.30. Found: $\mathrm{C}, 58.62 ; \mathrm{H}, 5.44 .{ }^{1} \mathrm{H} \mathrm{NMR}\left(\mathrm{CDCl}_{3}\right) \delta: 3.77\left(\mathrm{~s}, \mathrm{OCH}_{3}, 6 \mathrm{H}\right) ;(4.49(\mathrm{~s}, \mathrm{CH}, 1 \mathrm{H}) ; 5.24$ $\left(\mathrm{s}, \mathrm{CH}_{2}-\mathrm{Ph}, 2 \mathrm{H}\right) ; 7.34(\mathrm{~m}, \mathrm{Ph}, 5 \mathrm{H}) .{ }^{13} \mathrm{C} \mathrm{NMR}\left(\mathrm{CDCl}_{3}\right) \delta:\left(53.31\left(\mathrm{O}-\mathrm{CH}_{3}\right) ; 58.60(\mathbf{C}-\mathrm{H}) ; 68.05\right.$ $\left(\mathrm{CH}_{2}-\mathrm{Ph}\right) ; 128.24$ (C2',C6'-Ph); 128.56 (C4'Ph); 128.60(C3',C5' Ph); 134.80(C1'Ph); 163.61 $\left(\mathrm{CO}_{2} \mathrm{CH}_{2}-\mathrm{Ph}\right) ; 164.13\left(\mathrm{CO}_{2} \mathrm{Me}\right)$.

Trimethyl 2-chloro-1,1,1-ethanetricarboxylate (17). $0.380 \mathrm{~g} \mathrm{(2} \mathrm{mmol)} \mathrm{of} \mathbf{1 0}$ was added to a stirred suspension of $0.652 \mathrm{~g}(2 \mathrm{mmol})$ of anhydrous cesium carbonate in $10 \mathrm{~mL}$ of DMSO at 70 ${ }^{\circ} \mathrm{C}$. The mixture was stirred at $70{ }^{\circ} \mathrm{C}$ for $12 \mathrm{~h}$ and then treated with $0.706 \mathrm{~g}(4 \mathrm{mmol})$ of $\mathrm{CH}_{2} \mathrm{ClI}$. After stirring overnight at $70{ }^{\circ} \mathrm{C}$ the mixture was cooled to $\mathrm{rt}$ and worked-up. Yield $0.400 \mathrm{~g}$ 
(84\%). An analytical sample was obtained by crystallization from isopropyl ether mp 52.5 - 53.5 ${ }^{\circ} \mathrm{C}$. By using $\mathrm{K}_{2} \mathrm{CO}_{3}$ as base the yield increases to $89 \%$. Anal. Calcd. for $\mathrm{C}_{8} \mathrm{H}_{11} \mathrm{ClO}_{6}: \mathrm{C}, 40.25$;

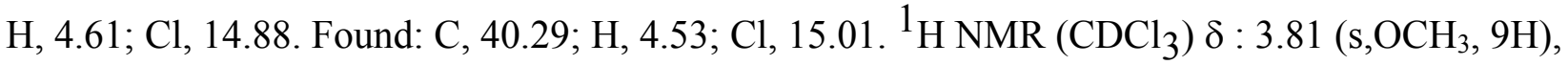
$4.06\left(\mathrm{~s}, \mathrm{CH}_{2}, 2 \mathrm{H}\right) .{ }^{13} \mathrm{C} \mathrm{NMR}\left(\mathrm{CDCl}_{3}\right) \delta: 43.04(\mathrm{C}-\mathrm{Cl}), 53.63\left(\mathrm{OCH}_{3}\right), 66.53\left(\mathrm{C}^{\mathrm{o}}\right), 164.88$ $(\mathrm{C}=\mathrm{O})$.

Trimethyl 2-bromo-1,1,1-ethanetricarboxylate (16). (a) From 10a. To $1.060 \mathrm{~g}$ (5 mmol) of 10a in $10 \mathrm{~mL}$ of DMSO was added $1.240 \mathrm{~g}(7 \mathrm{mmol})$ of $\mathrm{CH}_{2} \mathrm{Br}_{2}$ and heated with stirring at $70{ }^{\circ} \mathrm{C}$ during $12 \mathrm{~h}$. The mixture was poured into $40 \mathrm{~mL}$ of water and extracted with ether (4 x $20 \mathrm{~mL})$. The combined ether extracts were washed with water $(10 \mathrm{~mL})$ and brine $(10 \mathrm{~mL})$, dried over MgSO4 and evaporated. The crude product was purified by column chromatography. Yield 0.477 g. $(33 \%) \mathrm{mp} 66.8-67.6{ }^{\circ} \mathrm{C}\left({ }^{\mathrm{i}} \mathrm{Pr}_{2} \mathrm{O}\right)$. Anal. Calcd. for $\mathrm{C}_{8} \mathrm{H}_{11} \mathrm{BrO}_{6}: \mathrm{C}, 33.92 ; \mathrm{H}, 3.88 ; \mathrm{Br}, 28.27$. Found: C, 33.78; H, 3.75; Br, 27.98. ${ }^{1} \mathrm{H} \mathrm{NMR}\left(\mathrm{CDCl}_{3}\right) \delta: 3.82\left(\mathrm{~s}, \mathrm{OCH}_{3}, 9 \mathrm{H}\right), 3.89\left(\mathrm{~s}, \mathrm{CH}_{2} 2 \mathrm{H}\right)$. ${ }^{13} \mathrm{C} \mathrm{NMR}\left(\mathrm{CDCl}_{3}\right) \delta: 29.45(\mathrm{C}-\mathrm{Br}), 53.66\left(\mathrm{O}-\mathrm{CH}_{3}\right), 66.10\left(\mathrm{C}^{\mathrm{o}}\right), 164.99(\mathrm{C}=\mathrm{O})$.

(b) From 10b. $1.140 \mathrm{~g} \mathrm{(5} \mathrm{mmol)} \mathrm{of} \mathrm{the} 10 \mathrm{~b}$ in $10 \mathrm{~mL}$ of DMSO ws reacted with an excess $2.610 \mathrm{~g}$ (15 mmol) of $\mathrm{CH}_{2} \mathrm{Br}_{2}$ at $70{ }^{\circ} \mathrm{C}$ during $12 \mathrm{~h}$. After usual work-up yield $1.160 \mathrm{~g}$ of product (82\%).

(c) From 10b. To a stirred suspension of $0.138 \mathrm{~g}(1 \mathrm{mmol})$ of anhydrous potassium carbonate in 5 $\mathrm{mL}$ of DMSO at $70{ }^{\circ} \mathrm{C}$ was added $0.190 \mathrm{~g}(1 \mathrm{mmol})$ of 10 . The mixture was stirred at $70{ }^{\circ} \mathrm{C}$ for $12 \mathrm{~h}$ and then treated with $0.522 \mathrm{~g}(3 \mathrm{mmol})$ of $\mathrm{CH}_{2} \mathrm{Br}_{2}$. After stirring at $70{ }^{\circ} \mathrm{C}$ during $4 \mathrm{~h}$ the mixture was cooled to $\mathrm{rt}$ and worked-up. Yield $0.266 \mathrm{~g}(94 \%)$. Yields of product using other alkaline carbonates see Table 2.

(d) From bromoiodomethane and 10a. $1.060 \mathrm{~g}(5 \mathrm{mmol})$ of 10a in $10 \mathrm{~mL}$ of DMSO was reacted with $1.105 \mathrm{~g}(5 \mathrm{mmol})$ of $\mathrm{CH}_{2} \mathrm{BrI}$ at $70{ }^{\circ} \mathrm{C}$ during $20 \mathrm{~h}$. After usual work-up, the crude product was purified by column chromatography. Yield $0.482 \mathrm{~g}$. (34\%).

(e) From bromoiodomethane and 10. To a stirred suspension of $0.326 \mathrm{~g}(1 \mathrm{mmol})$ of anhydrous cesium carbonate in $5 \mathrm{~mL}$ of DMSO at $70{ }^{\circ} \mathrm{C}$ was added $0.190 \mathrm{~g}(1 \mathrm{mmol})$ of $\mathbf{1 0}$ and the mixture heated $12 \mathrm{~h}$. The cooled mixture was treated with $0.663 \mathrm{~g}(3 \mathrm{mmol})$ of $\mathrm{CH}_{2} \mathrm{BrI}$ and heated at 70 ${ }^{\circ} \mathrm{C}$ for $4 \mathrm{~h}$. After usual work-up, the product was isolated and analyzed by GC-mass spectrometry. Only two products were detected: $40 \%$ of bromoderivate 16 and $54 \%$ of iododerivate 15 .

Trimethyl 2-iodo-1,1,1-ethanetricarboxylate (15). (a) From 10a. To $1.060 \mathrm{~g}$ (5 mmol) of 10a dissolved in $10 \mathrm{~mL}$ of DMSO was added $1.340 \mathrm{~g}(5 \mathrm{mmol})$ of $\mathrm{CH}_{2} \mathrm{I}_{2}$ and the mixture stirred at 70 ${ }^{\circ} \mathrm{C}$ during $12 \mathrm{~h}$. The solution was cooled to $\mathrm{rt}$ and poured into $40 \mathrm{~mL}$ of water and extracted with ether $(3 \times 10 \mathrm{~mL})$. The combined ether extracts were washed with water $(10 \mathrm{~mL})$ and brine $(10$ $\mathrm{mL}$ ), dried over MgSO4 and evaporated. The crude product (1.544 g) was purified by column chromatography. Yield $1.006 \mathrm{~g}(61 \%) \mathrm{mp} 57.5-58{ }^{\circ} \mathrm{C}$. An analytical sample was obtained by crystallization from isopropyl ether. Anal. Calcd. for $\mathrm{C}_{8} \mathrm{H}_{11} \mathrm{IO}_{6}: \mathrm{C}, 29.11 ; \mathrm{H}, 3.36$; I, 38.45. Found: C, 29.33; H, 3.39; I, 38.32. ${ }^{1} \mathrm{H} \mathrm{NMR}\left(\mathrm{CDCl}_{3}\right) \delta$ : 3.71(s, $\left.\mathrm{CH}_{2}, 2 \mathrm{H}\right), 3.84\left(\mathrm{~s}, \mathrm{O}-\mathrm{CH}_{3}, 9 \mathrm{H}\right)$. ${ }^{13} \mathrm{C}$ NMR $\left(\mathrm{CDCl}_{3}\right) \delta:-0.37(\mathrm{C}-\mathrm{I}), 53.67\left(\mathrm{O}-\mathrm{CH}_{3}\right), 65.73\left(\mathrm{C} 4^{\circ}\right), 165,19(\mathrm{C}=\mathrm{O})$.

(b) From 10 and alkaline carbonates. To a stirred suspension of $0.326 \mathrm{~g}(1 \mathrm{mmol})$ of anhydrous cesium carbonate in $5 \mathrm{~mL}$ of DMSO at $70{ }^{\circ} \mathrm{C}$ was added $0.190 \mathrm{~g}(1 \mathrm{mmol})$ of $\mathbf{1 0}$. After $12 \mathrm{~h}$ the 
mixture was cooled and treated with $0.804 \mathrm{~g}(3 \mathrm{mmol})$ of $\mathrm{CH}_{2} \mathrm{I}_{2}$ and heated at $70{ }^{\circ} \mathrm{C}$ for $4 \mathrm{~h}$. After usual work-up, the product was isolated in $90 \%$ yield. The yields using other alkaline carbonate were: $\mathrm{K}_{2} \mathrm{CO}_{3} 82 \%, \mathrm{Na}_{2} \mathrm{CO}_{3} 67 \%$, and with $\mathrm{Li}_{2} \mathrm{CO}_{3} 49 \%$.

tert-Butyl dimethyl-2-iodo-1,1,1-ethanetricarboxylate (18). To a solution of $0.348 \mathrm{~g}$ (1.5 $\mathrm{mmol}$ ) of 11 in $7.5 \mathrm{~mL}$ of DMSO was added $0.489 \mathrm{~g}$ of cesium carbonate. The mixture was stirred at $70{ }^{\circ} \mathrm{C}$ for $5 \mathrm{~h}$, cooled to $\mathrm{rt}$, and $1.206 \mathrm{~g}(4.5 \mathrm{mmol})$ of $\mathrm{CH}_{2} \mathrm{I}_{2}$ were poured in and the mixture stirred at $70{ }^{\circ} \mathrm{C}$ for $12 \mathrm{~h}$. The solution was diluted with $20 \mathrm{~mL}$ of ethyl acetate, the organic phase washed with saturated solution of ammonium chloride $(10 \mathrm{~mL})$ and brine $(10 \mathrm{~mL})$, dried and evaporated to yield $0.513 \mathrm{~g}(92 \%)$ of the product as a colorless oil. An analytical sample was obtained by column chromatography. HRMS Calcd. for $\mathrm{C}_{11} \mathrm{H}_{17} \mathrm{INaO}_{6}$ : 394.99620 . Found: 394.99679. (Source Type ESI, Ion Polarity Positive) ${ }^{1} \mathrm{H}$ NMR $\left(\mathrm{CDCl}_{3}\right) \delta: 1.49$ (s,

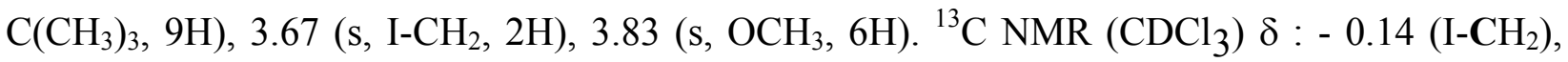
$27.70\left(\mathrm{CH}_{3}\right), 53.37\left(\mathrm{O}-\mathrm{CH}_{3}\right), 66.23\left(\mathbf{C} 4^{\circ}\right), 84.47\left(\mathbf{C M e}_{3}\right), 163.37\left(\mathbf{C O}_{2}{ }^{t} \mathrm{Bu}\right), 165.62\left(\mathbf{C O}_{2} \mathrm{Me}\right)$.

Benzyl dimethyl 2-iodo-1,1,1-ethanetricarboxylate (19). To a solution of $0.208 \mathrm{~g}$ (1 mmol) of 12 in $5 \mathrm{~mL}$ of DMSO was added $0.326 \mathrm{~g}$ of cesium carbonate. The mixture was stirred at $70{ }^{\circ} \mathrm{C}$ for $5 \mathrm{~h}$, cooled to $\mathrm{rt}$ and treated with $0.804 \mathrm{~g}(3 \mathrm{mmol})$ of $\mathrm{CH}_{2} \mathrm{I}_{2}$. The mixture was stirred at $70{ }^{\circ} \mathrm{C}$ for $12 \mathrm{~h}$, diluted with $20 \mathrm{~mL}$ of ethyl acetate, and the organic phase washed with aqueous $2 \%$ $\mathrm{HCl}$ and brine, dried and evaporated to yield $0.283 \mathrm{~g}(74 \%)$ of product as a colorless oil. An analytical sample was purified by column chromatography. Anal. Calcd. for $\mathrm{C}_{14} \mathrm{H}_{15} \mathrm{IO}_{6}: \mathrm{C}, 41.36$; H, 3.72;.I, 31.21. Found: C, 41.5; H, 3.85; I, 31.02. HRMS Calcd. for $\mathrm{C}_{14} \mathrm{H}_{15} \mathrm{INaO}_{6}: 428.98055$. Found: 428.97894. ${ }^{1} \mathrm{H}$ NMR $\left(\mathrm{CDCl}_{3}\right) \delta: 3.70\left(\mathrm{~s}, \mathrm{I}_{-} \mathrm{CH}_{2}, 2 \mathrm{H}\right), 3.77\left(\mathrm{~s}, \mathrm{OCH}_{3}, 6 \mathrm{H}\right), 5.25\left(\mathrm{~s}, \mathrm{CH}_{2^{-}}\right.$ $\mathrm{Ph}, 2 \mathrm{H}), 7.35(\mathrm{~m}, \mathrm{Ph}, 5 \mathrm{H}) .{ }^{13} \mathrm{C} \mathrm{NMR}\left(\mathrm{CDCl}_{3}\right) \delta:-0.42\left(\mathrm{I}^{\left.-\mathrm{CH}_{2}\right),} 53.56\left(\mathrm{O}-\mathrm{CH}_{3}\right), 65.84\left(\mathrm{C} 4^{\circ}\right)\right.$, $68.36\left(\mathrm{CH}_{2}-\mathrm{Ph}\right), 128.30$ (C2',C6'-Ph), 128.57 (C4'Ph and C3',C5'Ph), 134.61 (C1'Ph), 164.45 $\left(\mathrm{CO}_{2} \mathrm{CH}_{2}-\mathrm{Ph}\right), 165.10\left(\mathrm{CO}_{2} \mathrm{Me}\right)$.

\section{Acknowledgements}

JZ gratefully acknowledge the Consejo Nacional de Investigaciones Científicas y Técnicas (CONICET) and Universidad Nacional de Rosario (UNR) for support.

\section{Supplementary Materials}

Include ${ }^{1} \mathrm{H}$ and ${ }^{13} \mathrm{C}$ NMR spectra, GC-Mass spectra and IR spectra of selected examples appearing with the Paper. 


\section{References and Notes}

1. Simonsen, J. L. J. Chem. Soc. 1908, 93, 1777.

http://dx.doi.org/10.1039/CT9089301777

2. Dowd, P.; Shapiro, M. J. Am. Chem. Soc. 1976, 98, 3724.

http://dx.doi.org/10.1021/ja00428a065

3. Guthzeit, M.; Dressel, O. Berichte 1888, 21, 2233.

4. Guthzeit, M.; Dressel, O. Liebigs Annalen der Chemie 1890, 256, 171. http://dx.doi.org/10.1002/jlac.18902560108

5. Perkin, W.H.; Prentice, B. J.Chem.Soc. 1891,59, 990.

http://dx.doi.org/10.1039/CT8915900990

6. Tutin, F. J.Chem.Soc. 1907, 91. 1141. http://dx.doi.org/10.1039/CT9079101141

7. Zielinsky, N. Berichte. 1889, 22, 3294.

8. Auwers, K, Thorpe, J. F. . Liebigs Annalen der Chemie. 1895, 285, 310. http://dx.doi.org/10.1002/jlac.18952850304

9. Kötz, A,; Zörnig, W. J. Prakt. Chem. 1906, 74, 425. http://dx.doi.org/10.1002/prac.19060740130

10. Padgett, H. C.; Csendes, I. G.; Rapoport, H. J. Org. Chem. 1979, 44, 3492. http://dx.doi.org/10.1021/jo01334a009

11. Corson, B. B.; Sayre, J. L. Org. Synth., Coll. Vol. II. 1943, 596.

12. Ferreira, P. C.; Miyata, Y. An. Fac. Farm. Odont. Univ. S. Paulo 1962, 19, 45.

13. Miyata, Y.; Ferreira, P.C. Rev. Fac. Farm. Bioquim. S. Paulo 1967, 5, 305.

14. Böhme, H.; Háfner, L. Chem. Ber. 1966, 99, 281. http://dx.doi.org/10.1002/cber.19660990144

15. Prelicz, D.; Witek, H.; Wyzgowska, L. Rocz. Chem. 1967, 41, 267. Chem. Abstr. 1967, 67, $11147 \mathrm{n}$.

16. Reichardt, C. Solvents and Solvent Effects in Organic Chemistry; 3rd Edn. WILEY-VCH, Weinheim. 2003. Ch. 3.

17. Cope, A. C.; Holmes, H. L.; House, H. O. Org. Reactions 1957, 9, 139.

18. The iodocompounds $\mathbf{1 5}, \mathbf{1 8}$, and 19 react with zinc dust in THF to form the respective zinc homoenolates that can be reacted with electrophiles. Thus, for example, the zinc homoenolate of 15 treated with diluted acid solution yields $85 \%$ of $\mathbf{1 3}$ and, previous transmetallation with Knochel couprate $(\mathrm{CuCN} .2 \mathrm{LiCl})$ reacted with benzoyl chloride to give $60 \%$ of trimethyl 3oxo-3-phenyl-1,1,1-propanetricarboxylate (unpublished results). Similar yield was obtained in an alternative way from 10a and bromoacetophenone. ${ }^{14}$

19. Miyano, S,; Hashimoto. H. Bull.Chem.Soc. Japan 1971, 44, 2864. 